\title{
Editorial
}

For some time, the future of Leprosy Review had been a matter of interest and concern to both the Medical Committee and the Executive Committee of LEPRA (The British Leprosy Relief Association).

In these days of mergers and rising costs, of streamlining and rapid communication, it was inevitable that the usefulness and the viability of Leprosy Review had to be considered very seriously. Notwithstanding the existence of sister-organs in English (notably the International Journal of Leprosy and Leprosy in India), in French, in Spanish and in Japanese, and notwithstanding, furthermore, the welcome now being accorded by a variety of general and more specialized journals to articles embodying the results of research into some aspect of leprosy, it was considered that Leprosy Review was fulfilling an important and necessary function.

Leprosy Review will therefore continue to be published, with the backing and support of LEPRA, in the belief that it will, as in the past, serve the cause of leprosy by the prompt dissemination of information to its readers engaged in many branches of leprosy, thus stimulating good work in the field, the operating theatre and the wards, the laboratory, the workshop.

James Ross Innes has left his mark on Leprosy Review, and his untimely death (to which reference is made elsewhere in this issue) involves the bringing forward by some months of proposals that were intended to come into effect early next year. Although he continued to edit the Review after relinquishing the post of Medical Secretary of LEPRA, it had latterly become obvious that his failing health brought nearer the unwelcome but inevitable necessity for change. With the approval of the Executive Committee of LEPRA, therefore, the Medical Committee had already taken steps to ensure continuity of publication and continuity of editorial policy.

The Editor is replaced by an Editorial Board, constituted as follows:-

\author{
Drs. S. G. Browne (Chairman). \\ R. J. W. Rees (Vice-Chairman). \\ S. R. M. Bushby. \\ W. H. Jopling. \\ D. S. Ridley.
}

This Board will be responsible to the Medical Committee of LEPRA for the contents of Leprosy Review. It will, through its Chairman, receive articles submitted for publication and decide matters of policy.

The address of the Chairman of the Editorial Board, to whom all communications concerning the contents of Leprosy Review should in the future be directed, is:-

57A Wimpole Street,

London, W.1, England.

The Board will be assisted in its work by a part-time Sub-Editor, Dr. A. D. Duff, a medical man with considerable experience in medical journalism both in England and abroad. He will be responsible for the routine preparation for publication of accepted articles, illustrations, layout, etc.

\section{Publishers of Leprosy Review}

Leprosy Review has hitherto been published by The British Leprosy Relief Association, which has generously subsidized the costs of publication over the years. From the first number of the next volume (due to appear in January, 1969), The Academic Press Inc. (London) Ltd. will assume the duties and risks (and possible benefits) of publishing the Review, including the collection of subscriptions, sale of back numbers, etc. The implementation of this new arrangement will not need to be brought forward by reason of the lamented death of Dr. Ross Innes. As from 1 January, 1969, therefore, the whole of the business side of Leprosy Review will be handled by The Academic Press Inc. (London) Ltd., whose address is:-

Berkeley Square House, Berkeley Square, London, W.1, England. 
A further and more detailed announcement will be made in the October, 1968, issue of Leprosy Review.

The procedure proposed is in keeping with that already adopted by many professional journals, and we look forward to a period of still greater efficiency and effectiveness in the dissemination of new knowledge about the diverse aspects of leprosy.

\section{Note}

Three titles of interest to readers of Leprosy Review have recently been added to the library of recorded talks on medical subjects sponsored by the Medical Recording Service and Sound Library of the Royal College of General Practitioners (Great Britain).

The author of the tapes is Dr. S. G. Browne, o.B.E., Medical Secretary of LEPRA.

No. 68/21 ('The recognition and management of leprosy in the tropics') is illustrated with 47 coloured transparencies. This should serve as a useful introduction to practitioners in the tropics who are not specializing in leprosy but who want to know more about this disease.

No. 68/22 ('Leprosy is here-in Great Britain'), illustrated with 23 transparencies, is intended for the general practitioner in countries like Britain where leprosy is but rarely met with, and is almost confined to the immigrant population. It tells the practitioner how to recognise leprosy and what to do if he suspects that a patient of his might have the disease.
$68 / 23$ ('Bringing you up to date with leprosy') is intended for general medical audiences desiring information on recent advances in leprosy research in the fields particularly of microbiology, animal transmission of $M$. leprae and therapeutics. This will supplement the recording made some years ago by Dr. J. Ross Innes which was sponsored by ICI Ltd., who have also contributed to the cost of the present recording.

The tapes are on $5 \mathrm{in}$. reels, and run at a speed of $3 \frac{3}{4}$ i.p.s.

Tapes, with accompanying slides, may be borrowed from: Dr. John Graves, o.B.E., Kitts Croft, Writtle, Chelmsford, Essex, for 5 shillings each (plus postage) for 14 days' hire. Prices for purchase may be obtained from Dr. Graves.

\section{Erratum}

We wish to draw attention to a misprint in the April issue of Leprosy Review in the paper, 'Presence of $M$. leprae in the Nipple Secretion and Lumina of the Hypertrophied Mammary Gland' by Dr. J. C. Pedley.

p. 67 , right-hand col., line $26-27$

'. . . all of which were in good solid rod form' should read

'. . . 11 (eleven) of which were in good solid rod form'.

S. G. BRowne. Chairman, Editorial Board, Leprosy Review.

\section{Ninth International Leprosy Congress LONDON}

SEPTEMBER 16-21, 1968

at The Imperial College of Science and Technology

Prince Consort Road

South Kensington

London, S.W.7 